\title{
ASPEK KEARIFAN LOKAL DALAM PELESTARIAN LINGKUNGAN
}

\author{
${ }^{1}$ Husni Thamrin \\ ${ }^{1}$ Program Pascasarjana \\ Universitas Islam Negeri Sultan Syarif Kasim Riau \\ husni2017husni@gmail.com
}

\begin{abstract}
One of the ironiesof the development of human civilizationis the development and modernization is intended to improve the quality of human life, but it is more often the presence of people become victims of development and modernization. More ironically, land and indigenous peoplesare victims of an anthropocentricpers pectiveand government policies that do not favor the local community. This is attributable to several factors: First, the ideology of developmentalism does not incorporate local wisdom, especially regarding indigenous land policy and management and wealth preservation socio-economic-cultural as an integral part of all development programs. In the ideology of developmentalism traditionalism is the opposite of modernization so that all that is traditional, including indigenous lands rich culture and local wisdom considered adaptive in the times. Second, misperceptions people who think the indigenous people of Rokan Hilir as a destroyer of the environment that must be removed or relocated in order to save the environment. Yet, precisely Rokan Hilir indigenous peoples are the guardians of the environment from the invasion and destruction by outside communities, immigrant communities. Third, the nature only in terms of economic value, so that the release of the entire ecological value, the local political, social, cultural, spiritual and moral associated with customary land and the lives of indigenous peoples in the surrounding. Exploit indigenous lands and natural resources for the purpose of economic development and seen off as not have negative consequences for the existence of the indigenous population. Fourth, modernization and progress of civilization seen and measured primarily by the quality of the physical-economic-capitalistic. Toimprove thesocioeconomiclevelof local communities, especiallythe Malaysmust bereturnedto theethical valuesof indigenous peoples. Socio-economicrights ofindigenous peoples should berecognized and guaranteedby the government. There must bepolitical commitmentatglobal and national levelstoprotectthe land rights ofindigenouspeoples andall the wisdomof socioeconomicThroughparadigm approacheco-culture istosave the existence ofindigenous landas a factorsupportingeconomic activityand allthe wealthandwisdom oftraditional, it can also besave theecological crisisis mainlycaused by faultyworldviewthatpolicy makersanthropocentric-capitalistic paradigmshould be changedtoeco-culture perspective.
\end{abstract}


Keyword : Local Wisdom, socio-economic, ecoculture, and anthropocentric

\section{PENDAHULUAN}

Kearifan lokal masyarakat adat Melayu mengalami erosi, atau kritis sebagian terdegradasi yang disebabkan beberapa faktor.terjadi proses desakralisasi alam oleh invasi dan dominasi kegiatan ekonomi kapitalistik yang antroposentrikkapitalistik dan teknologi modern. Alam yang dipahami sebagai sakral oleh masyarakat adat Melayu dan menyimpan sejuta nilai nilai kearifan lokal yang telah lama mengakar dalam kehidupan masyarakat bisa dijelaskan dengan menggunakan akal budi, sehingga membangkitkan sikap kagum penuh rasa hormat, sakralitas dan misterinya telah dieleminir dalam paradigma antroposentrik-kapitalistik dan teknologi modern. Dalam paradigma antroposentrik yang positivistik-kapitalistik, alam dipahami sebagai sekadar fakta yang profan tanpa getaran sakral-magis-religius, tanpa nilai dan muatan moral sama sekali. Alam direduksi sekadar sebagai obyek dan fakta yang bisa dipilahpilah, dianalisis dan dijelaskan secara ilmiah-rasional. Fenomena alam yang dipahami sebagai misteri ternyata dalam perspektif ilmu pengetahuan modern hanya problem yang bisa dijelaskan secara ilmiah dan rasional: bahwa ternyata alam dan semua kehidupan serta benda di dalamnya terdiri dari berbagai unsur kimia, fisika, dan biologi yang bisa diuraikan. Interaksi berbagai unsur kimia, fisika, dan biologi tersebutlah yang menimbulkan berbagai fenomena alam'yang menimbulkan rasa kagum, takut, dan takjub. Ternyata semua hal itu sebagai sebuah fenomena alam yang rasional-ilmiah yang berjalan secara posistivistik.

Paradigma antroposentrik telah menjauhkan manusia dari alam, sekaligus menyebabkan sikap eksploitatif dan tidak peduli terhadap alam. Dalam kaitan dengan itu, krisis ekologi dilihat pula sebagai disebabkan oleh cara pandang mekanistis-reduksionistis-dualistis dari ilmu pengetahuan Cartesian tersebut. Cara pandang yang antroposentris dikoreksi oleh etika bio-sentrisme dan ekosentrisme, khususnya Deep Ecology, untuk kembali melihat alam sebagai sebuah komunitas etis(Keraf, 2010).

Konsep eco-culture sesungguhnya sudah sejak awal mula dipraktikkan oleh masyarakat adat Melayu atau masyarakat-masyarakat tradisional di tempat lainnya.Cara pandang mengenai manusia sebagai bagian integral dari alam, serta perilaku penuh tanggung jawab, penuh sikap hormat dan peduli terhadap kelangsungan semua kehidupan di alam semesta, telah menjadi cara pandang dan perilaku berbagai masyarakat Melayu,

Sebagian kearifan lokal sosial ekonomi Melayu dalam pemeliharaan lingkungan hidup di antaranya masih tetap bertahan di tengah hempasan arus pergeseran oleh desakan cara pandang antroposentrik. Ada pula yang sedang mengalami krisis karena desakan pengaruh modernisasi tersebut. Sementara yang lain, hanyut terkikis hilang ditelan modernisasi dan cara pandang yang antroposentrik.Untuk itu diperlukan solusi yang akurat untuk menjawab tantangan zaman yang semakin hari semakin mencemaskan kehidupan manusia sebagai akibat keserakahan umat manusia.

\section{Antroposentrik Mengkikis Nilai Nilai Masyarakat Adat}

Vandana Shiva dalam Keraf
(2010) melihat bahwa dalam proses
modernisasi telah menyebabkan
masyarakat tradisional tercerabut dari
akar budayanya. Religiusitas dan
spiritualitas masyarakat adat yang
berkisar pada alam, telah digantikan
oleh modernisasi sebagai agama dan


spiritualitas baru. Ada korban yang tidak lagi berbentuk sesajen, melainkan berbentuk manusia, individu ataupun kelompok, yang terpaksadikorbankan demi modernisasi dan pembangunan sebagai agama baru. "Bendungan, tambang, pembangkit listrik, basis militer semua ini adalah kuil agama baru yang disebut 'pembangunan'.Apa yang dikurbankan di altar agama ini adalah kehidupan alam dan kehidupan manusia. Sakramen pembangunan terdiri dari keruntuhan dan desakralisasi hal-hal sakral lainnya. Ketika alam yang sakral telah kehilangan sakralitasnya dan dilihat sekadar sebagai sumber daya untuk pembangunan, maka alam pun dihancurkan tanpa ketakutan magis sama sekali.

Dalam arus modernisasi itu, kearifan tradisional tidak saja terkikis modernisasi, tetapi juga dirusak oleh dominasi pandangan antroposentrik. Selain modernisasi dan dominasi antroposentrik memarjinalisasikan kearifan lokal masyarakat Adat yang bernilai filosopi yang sangat tinggi, terjadi pula invasi cara pandang dan gaya hidup masyarakat yang antroposentris dan pragmatis. Karena segala sesuatu ditempatkan dalam kerangka kepentingan ekonomi manusia dan dalam kerangka penjelasan rasional-positivistik, kearifan lokal yang tidak memenuhi kedua kriteria itu lalu punah dilindas cara berpikir antroposentrik.Kearifan dan pengetahuan masyarakat adat Rokan Hilir sama sekali tidak diakui sebagai pengetahuan, bahkan dikecam sebagai yang gaib-irasional. Maka, segala kearifan dan praktik hidup beserta nilai-nilainya yang begitu kaya, khususnya dalam kaitan dengan alam, disingkirkan dari masyarakat modern.

Dominasi filsafat dan etika

positivistik yang bersumber dari Aristoteles dan diperkuat oleh paradigma antroposentrik telah menguburkan etika masyarakat adat
Melayu . Dengan melihat manusia hanya sebagai makhluk sosial, dan dengan membatasi etika sebagai hanya berlaku bagi komunitas manusia, etika masyarakat adat Melayu sebagian besar telah dilupakan sama sekali oleh masyarakat modern. Hubungan manusia dengan alam dalam komunitas ekologis sebagaimana dikenal dalam masyarakat adat dinafikan sama sekali. Etika masyarakat adat Adat yang dipahami sebagai berlaku untuk semua relasi kehidupan dalam alam, juga disingkirkan dari benak dan praktik hidup masyarakat adat. Karena dominasi filsafat antroposentrik, yang menghilang warisan etika masyarakat adat Melayu dari wacana publik masyarakat saat ini.

Hilangnya keanekaragaman hayati sebagai akibat dari modernisasi dengan "pembangunan" sebagai agama masyarakat modern, terjadi kehancuran dan kepunahan keanekaragaman hayati yang begitu kaya dalam masyarakat tradisional Melayu Rokan Hilir .Dampak timbal baliknya adalah, semakin punah keanekaragaman hayati itu semakin punah dan terkikis pula kearifan tradisional Melayu dengan segala nilainya, karena kearifan tradisional terkait erat dengan keanekaragaman hayati.Kearifan tradisional hanya mungkin dipertahankan kalau alam dan segala kekayaan di dalamnya masih tetap dipelihara. Ketika alam dengan segala kekayaannya terancam punah, punah pula seluruh kearifan tradisional tersebut.

Hilangnya sebagian besar hakhak tanah adat masyarakat adat Rokan Hilir, termasuk hak untuk hidup dan bertahan sesuai dengan identitas dan keunikan tradisi budayanya serta hak untuk menentukan diri sendiri. Di tengah invasi dan dominasi masyarakat modern karena pengaruh antroposentrik, masyarakat adat Rokan Hilir yang berbeda tradisi budayanya dan kehilangan hak tanah 
adat. Ini terjadi baik karena kolonialisme dan imperialisme, maupun karena modernisasi Barat membawa dampak tersingkir dan punahnya masyarakat adat di seluruh dunia. Apa yang mereka kenal seumur hidup tidak mendapat tempat dalam kerangka hukum dan etika modern. Bersamaan dengan hilangnya hak-hak tanah adat masyarakat adat Rokan Hilir, hilang pula kearifan lokal mereka yang begitu menentukan cara beradanya masyarakat adat Rokan Hilir itu. Sebaliknya, dengan hilangnya tanah adat tersebut itu, maka terancam pula keberadaan masyarakat adat Melayu Rokan Hilir. Salah satu ironi dari perkembangan peradaban manusia adalah, pembangunan dan modernisasi dimaksudkan untuk meningkatkan kualitas lingkungan hidup kehidupan manusia, termasuk masyarakat adat Rokan Hilir, tetapi justru lebih sering keberadaan tanah adat dan masyarakat Rokan Hilir menjadi korban dari pembangunan dan modernisasi tersebut. Lebih ironis lagi, tanah dan masyarakat Rokan Hilir menjadi korban dari cara pandang antroposentrik dan kebijakan pemerintah sejak kolonialisme hingga era pemerintahan Indonesia.

Hal ini terjadi kerena beberapa faktor: Pertama, ideologi developmentalisme tidak memasukkan kearifan lokal Melayu Rokan Hilir terutama menyangkut tanah adat dalam kebijakan pengelolaan lingkungan hidup dan pelestarian kekayaan sosial-budaya sebagai bagian integral dari seluruh program pembangunan. Dalam ideologi developmentalisme tradisionalisme adalah lawan dari modernisasi sehingga semua yang tradisional, termasuk tanah adat kekayaan budaya dan kearifan lokal di Rokan Hilir dianggap tidak adaptif dalam perkembangan zaman. Kedua, kesalahan persepsi masyarakat yang menganggap masyarakat adat Rokan Hilir sebagai perusak lingkungan hidup yang harus disingkirkan atau direlokasi demi menyelamatkan lingkungan hidup. Padahal, justru masyarakat adat Rokan Hilir adalah penjaga lingkungan hidup dari serbuan dan pengrusakan oleh masyarakat luar, masyarakat pendatang. Ketiga, alam hanya dilihat dari segi nilai ekonomisnya, sehingga dilepaskan dari seluruh nilai ekologis, politis lokal, sosial, budaya, spiritual dan moral yang terkait dengan tanah adat dan kehidupan masyarakat adat Rokan Hilir di sekitamya. Mengeksploitasi tanah adat dan kekayaan alam demi tujuan pembangunan ekonomi lalu dilihat secara lepas seakan tidak mempunyaidampak buruk bagi keberadaan masyarakat adat setempat. Keempat, modernisasi dan kemajuan peradaban dilihat dan diukur terutama berdasarkan kualitas fisikekonomis-kapitalistik. Tanah adat beserta kekayaan dan nilai budaya, sosial, spiritual, dan moral yang melekat pada dan dimiliki masyarakat adat dianggap tidak mempunyai nilai ekonomis bagi modernisasi dan kemajuan peradaban.

\section{Eco-culture : Sebuah Pemecahan masalah sosial-economi-ecologis}

Dalam konteks culture,

khususnya Deep Ecology, mendorong untuk meninggalkan cara pandang yang antroposentris, dan ketika cara pandang kehidupan yang holistik mengajak untuk meninggalkan cara pandang antroposentrik, manusia sesungguhnya diajak untuk kembali ke kearifan lokal, kearifan lama masyarakat adat Melayu. Dengan kata lain, etika lingkungan hidup orang Melayu adalah menghimbau dan mengajak manusia saat ini untuk kembali ke etika masyarakat adat Melayu yang masih relevan dengan perkembangan zaman. Inti pandangan ini adalah kembali ke alam, kembali ke jatidirinya sebagai manusia Melayu yang ekologis. Etika lingkungan hidup sesungguhnya menyadarkan orang Melayu untuk tidak terperangkap dan 
Al-Fikra: Jurnal Ilmiah Keislaman, Vol. 16, No. 2, Juli - Desember, 2017 (354 365)

terbuai oleh cara pandang antroposentris untuk kembali menghayati cara pandang eco-culture dan kearifan masyarakat adat Melayu.

Atas dasar itu, perlu meninjau kearifan atau pengetahuan masyarakat adat di berbagai kawasan tentang manusia, alam, dan hubungan manusia dengan alam. Tinjauan akan dipusatkan pada tiga hal. Pertama, cara pandang masyarakat adat Melayu tentang dirinya, alam dan hubungan antara manusia dan alam. Kedua, kekhasan pengetahuan tradisional yang dimiliki masyarakat adat Melayu sekaligus menentukan pola hidup dan perilaku masyarakat adatnya terhadap alam. Ketiga, hakhak masyarakat adat Melayu yang perlu dilindungi, karena dengan melindungi hak-hak mereka, tidak saja eksistensi masyarakat adat ini dilindungi, tetapi juga etika mereka serta alam yang menjadi sasaran. Terjadi desakralisasi alam, yang membuat alam tidak lagi menarik untuk dihormati, disembah, dan dipelihara penuh takjub. Maka, manusia pun melihat dirinya begitu agung dan superior berhadapan dengan alam yang tidak berarti sama sekali. Oleh karena itu, sikap hormat, perilaku merawat, mencintai dan menjaga keharmonisan atau hubungan baik dengan alam menjadi tidak relevan dan tidak punya tempat lagi. "Desakralisasi(alam) terjadi melalui perubahan makna ruang (space). Ruang yang sakral, pusat segala makna dan kehidupan, sumber ekologis dari keberlangsungan hidup, diubah menjadi sekadar tempat (site), lokasi dalam pandangan antroposentrik. Padahal dalam pandanganorang Melayu hubungan manusia-alam-Allah adalah relasi metafisis religious yang sacral, banyak pantang larang dan petuah yang esensinya bersumber dari Al-Quran dapat dilihat relasi dengan alam dalam surat al-Baqarah (2): 164

Sesungguhnya dalam
penciptaan langit dan bumi, silih

bergantinya malam dan siang, bahtera yang berlayar di laut membawa apa yang berguna bagi manusia, dan apa yang Allah turunkan dari langit berupa air, lalu dengan air itu Dia hidupkan bumi sesudah mati (kering) nya dan Dia sebarkan di bumi itu segala jenis hewan, dan pengisaran angin dan awan yang dikendalikan antara langit dan bumi; Sungguh (terdapat) tandatanda (keesaan dan kebesaran Allah) bagi kaum yang memikirkan.

Regulasi hukum dan kebijakan hanya untuk kepentingan nilai ekonomis kapitalistik telah memarjinalkan keberadaan tanah adat orang Melayu sebagai contoh kasus keberadaan Tanah Orang Melayu Rokan Hilir yang luas $8.881,59 \mathrm{~km}^{2}$ atau 888.159 hektar. Namun Keberadaan tanah orang adat di Rokan Hilir (20150 di daerah Bangko terdapat di perbatasan LengadaiBantaian Hilir seluas 500 Ha,di Bangko Pusako seluas $200 \mathrm{Ha}$. Tanah adat di Kubu terdapat di Teluk Nilap seluas $200 \mathrm{Ha}$. Jojol, Sei Panji-panji seluas $200 \mathrm{Ha}$ dan di Pulau jemur seluas $200 \mathrm{Ha}$. Sedangkan di Tanah Putih terdapat di Pulau Tilan seluas 410,4 Ha.

Keberadaan Tanah Adat di Rokan Hilir pada masa Kesultanan Siak (1772-1942) pada saat ini keadaannya sudah mengalami krisis. Upaya-upaya untuk menghilangkan keberadaan tanah adat ini sudah mulai ada sejak zaman Kolonial Belanda. Ini dapat dilihat pada kebijakan yang di keluar oleh pemerinah Kolonial maupun produk hukum yang dikeluarkan pada masa pemerintahan Indonesia seperti (1) Agrarische Wet stablat 1870 No 55; (2) Kontrak politik Belanda 1885; (3)Besluit 1915; (4) Undang-Undang No 13 tahun 1948 dan Undang-Undang 1950; (5) UUPA No tahun 1960; dan (6) UU No 5 Tahun 1979. Regulasi hukum yang di keluarkan ini telah memarjinalkan keberadaan tanah adat di Rokan Hilir Ada kekayaan yang melimpah ruah dalam alam yang harus 
dieksploitasi demi mengubah kehidupan manusia. Modernisasi menawarkan pola hidup baru yang bertentangan secara diametral dengan pola hidup masyarakat adat Melayu . Hidup selaras dengan alam dalam kesederhanaan alam dikutuk sebagai keterbelakangan yang harus ditinggalkan. Jalan untuk itu adalah mengeksploitasi dan mengorbankan alam demi kenikmatan ekonomis manusia yang bersifat pragmatis.Alam harus diubah, demikian pula kehidupan alamiah harus diubah. Manusia tidak boleh lagi bergantung pada alam, melainkan bergantung pada dirinya sendiri dengan kekuatan akal budi dan teknologi dengan menaklukkan dan mengubah alam. Karena manusia tidak lagi bergantung pada alam, seluruh kearifan lokal menjadi tidak penting lagi. Kearifan lokal hanya punya arti ketika hidup manusia bergantung pada dan ditentukan oleh alam, oleh nasib. Dengan mempraktekkan kearifan lokal, masyarakat adat Rokan Hilir menjamin bahwa alam dan nasib masih memberinya kehidupan. Semua ini hilang ketika dengan pandangan antroposentrik teknologi dan modernisasi manusia bisa menentukan nasib hidupnya.

Dengan demikian, segala pengetahuan tradisional yang bernilai ekonomis tinggi dipertahankan dan ditransformasikan ke dalam pandangan antroposentrik sambil menutup jejak asalnya sama sekali pada kearifan lokal. Bukti paling nyata adalah pengetahuan botani dan penyembuhan tradisional masyarakat maasyarakat adat Rokan Hilir yang diambil alih dengan sedikit sekali meninggalkan jejak tradisionalnya, seakan merupakan penemuan asli masyarakat ilmiah modern.Hal ini diteruskan dalam rezim orde Suharto ntuk semakin menghapus jejak asli sumber penghasilan ekonomi pada masyarakat lokal

Untuk menyelamatkan tanah adat Melayu Rokan Hilir harus kembali ke nilai-nilai etika masyarakat Melayu. Hak-hak masyarakat adat Melayu harus diakui dan dijamin oleh pihak pemerintah. Harus ada komitmen politik di tingkat global dan nasional untuk melindungi hak-hak tanah adat masyarakat adatMelayu beserta seluruh kearifan tradisionalnya. Melalui pendekatan paradigma ecoculture ini untuk menyelamatkan keberadaan tanah adat beserta seluruh kekayaan dan kearifan tradisionalnya, melainkan juga menyelamatkan krisis ekologi yang terutama disebabkan oleh kesalahan cara pandang dan perilaku masyarakat yang berparadigma antroposentrik.

Komitmen politik dan moral ke arah itu telah muncul dan disepakati dalam berbagai forum dan oleh berbagai kelompok intemasional. Komitmen politik dan moral ini muncul bersamaan dengan mengemukanya isu lingkungan hidup di satu pihak dan meningkatnya kesadaran mengenai nilai kearifan tradisional di pihak lain. Krisis ekologi sekarang ini tidak saja menimbulkan kritik tajam terhadap paradigma antroposentrik. Krisis ekologi juga menimbulkan kesadaran baru bahwa krisis ekologi bisa diselamatkan dengan kembali kepada kearifan tradisional, etika masyarakat adat. Oleh karena itu, hak-hak tanah adat masyarakat adat harus diakui dandijamin demi menyelamatkan kearifan dan etika masyarakat adat Melayu Rokan Hilir.

Dalam buku Cultural and Spiritual Values of Biodiversity dapat ditemukan banyak sekali pernyataan atau deklarasi mengenai hak-hak masyarakat adat. Hal yang paling menonjol adalah, tuntutan tentang perlindungan atas hak-hak masyarakat adat yang merupakan sebuah kecenderungan global yang perlu disambut gembira. Dari fenomena dan observasi lapangan ditemukan lemahnya dasar hukum dan perlindungan politik terhadap hak-hak 
tanah adat dan masyarakat adat. Di tengah maraknya deklarasi-deklarasi penyelamatan lingkungan ada kecenderungan globalisasi untuk melupakan eksistensi tanah adat masyarakat adat beserta hak-haknya. Sedangkan disisi lain, di tengah upaya pembangunan ekonomi nasional, yang terutama bertumpu pada sumber daya alam,tidak ada implementasi dalam bentuk perlindungan hukum nasional yang signifikan terhadap tanah adat dan masyarkat adat Rokan Hilir.

Dalam kasus tanah adat di Rokan Hilir,misalnya, belum ada langkah politik yang signifikan untuk melindungi secara hukum hak-hak tanah adat masyarakat adat. Padahal, tanah adat dan masyarakat adat merupakan esensi untuk melindungi dan simbol identitas budaya Rokan Hilir. Dengan kata lain, terjemahan komitmen politik dan moral pada tingkat global ke tingkat nasional masih belum memuaskan. Bahkan, sebagaimana dikatakan oleh Darrell Addison Posey,dalam Keraf (2010) "Banyak negara bahkan tidak mengakui hak-hak dasar suku-suku asli untuk hidup, apalagi menjamin bagi mereka hak untuk menentukan nasib sendiri, hak milik atas tanah adat, atau hak untuk menguasai sumber-sumber daya tradisionainya.Oleh karena itu perlu komitmen dan langkah politik yang signifikan untuk melindungi tanah adat dalam perspektif eco-culture.

Persolan yang penting disini adalah, masyarakat dan negara modern menggunakan hukum positif untuk menilai keberadaan masyarakat adat dengan seluruh kekayaan dan kearifan tradisionalnya. Ketika masyarakat adat dinilai dalam perspektif hukum positif masyarakat dan negara modern, seluruh hak dan kekayaan yang dimiliki masyarakat adat tidak akan pernah diakui, karena hak-hak masyarakat adat itu tidak ada dalam hukum positif. Hal ini terlihat, tidak ada dasar hukum positif bagi kepemilikan tanah adat dan wilayah masyarakat adat Melayu. Bahkan tanah adat di Melayu dan seluruh kekayaan alam termasuk keanekaragaman hayati disekitarnya yang dimiliki secara turun temurun oleh masyarakat adat Rokan Hilir tidak diakui secara legal karena tidak diatur dalam hukum positif. Tanah adat dan seluruh kekayaan tersebut disebut liar termasuk keanekaragaman hayati: binatang liar dan tanaman liar. Karena dianggap liar, yang berarti bebas dan menjadi milik publik, siapa saja boleh menjarahnya, termasuk masyarakat, negara, dan orang-orang dari luar (bahkan orang asing dalam kaitan dengan biopiracy) (Keraf, 2010). Dengan pendekatan antroposentrik ini, segala penjarahan dan pencurian kekayaan masyarakat adat dianggap sah dan dibenarkan, karena tidak ada dasar hukum yang melarangnya, apalagi kekayaan itu dianggap liar Untuk melindungi keberadaan tanah dan masyarakat adat beserta seluruh kekayaan tradisi budayanya, termasuk kearifan tradisionalnya dan dalam rangka untuk melindungi keanekaragaman hayati beberapa hak masyarakat adat berikut ini perlu diakui, dijamin dan dilindungi dengan pendekatan eco-culture. Pertama, hak untuk menentukan diri sendiri identitas dan budaya Rokan Hilir. Ini merupakan hak moral dan legal yang melekat pada eksistensi masyarakat adat Rokan Hilir sebagai manusia yang berperadaban. Oleh karena itu, sebagaimana berlaku bagi semua negara bangsa di dunia, hak untuk menentukan diri sendiri harus pula diakui, dijamin dan dilindungi untuk masyarakat adat. Tentu saja ini tidak berarti masyarakat adat Rokan Hilir akan membentuk negara bangsanya sendiri. Yang menjadi sasaran utama dari hak ini adalah, masyarakat adat mempunyai posisi legal dan moral yang setara dengan kelompok masyarakat peradaban lainnya untuk didengar dan dilibatkan dalam semua prosespolitik yang menentukan nasib mereka. Masyarakat adat di Rokan 
Hilir tidak boleh diabaikan, dan nasib mereka tidak boleh ditentukan secara sepihak oleh pihak luar. Demikian pula, seluruh kekayaan merekatermasuk tanah adat, dan budaya harus diakui mempunyai status legal, khususnya dalam perspektif hukum kodrat atau hukum adat, sehingga harus diakui pula oleh hukum positif.

Termasuk dalam hak untuk menentukan nasib sendiri adalah hak untuk pindah tempat tinggal, hak untuk mempertahankan atau meninggalkan tradisi budaya, hak untuk meninggalkan atau mempertahankan gaya hidup.Masyarakat adat mempunyai hak penuh untukmelalui mekanisme adat yang mereka milikimenentukan pola pengaturan hidup bersama di dalam kelompoknya, dan untuk menjadi apa saja dalam segala dimensi kehidupannya: ekologis, ekonomi, budaya, sosial, dan politik.

Kedua, hak teritori dan tanah adat. Ini penting karena tanah adat terkait secara langsung dengan eksistensi mereka. Tanah adat tidak dapat dipisahkan dari keberadaan mereka beserta seluruh tradisi budayanya. Oleh karena itu, merampas teritori dan tanah adat mereka, atas nama apa saja, merupakan sebuah pengingkaran dan pemusnahan terhadap eksistensi masyarakat adat. Maka, hak atas teritori dan tanah merupakan hak paling fundamental bagi masyarakat adat.

Deklarasi Hak Suku-suku Asli dari PBB, Bagian VI, mengakui bahwa "Suku-suku asli mempunyai hak untuk mempertahankan dan memperkuat hubungan spiritual dan material mereka yang khas dengan tanah adat, teritori, air, dan laut dan sumbersumber daya yang mereka miliki, diami, atau gunakan secara turuntemurun, dan bertanggung-jawab atas generasi yang akan datang dalam soal ini." Demikian pula, "Suku-suku asli mempunyai hak untuk memiliki, mengembangkan, menguasai dan menggunakan tanah dan teritori, termasuk seluruh lingkungan tanah, udara, air, laut, lautan es, flora dan fauna dan sumber-sumber daya lain yang mereka miliki, diami atau gunakan secara turun-temurun. Ini mencakup hak atas pengakuan penuh atas hukum, tradisi, adat-istiadat, sistem teritorial tanah dan institusiinstitusi mereka untuk pembangunan dan pengelolaan sumber daya, dan hak atas langkah efektif negara untuk mencegah campur tangan apa pun, perampasan atau pelanggaran atas hak-hak mereka(Shiva,1976 dalam Keraf ,2010).

Termasuk di dalam hak atas tanah adat dan teritori ini adalah hak untuk tidak dipindahkan dari tanah leluhurnya, hak untuk menggunakan tanah dan sumber daya alam yang ada di dalam tanah milik mereka, dan hak untuk melindungi tanah milik mereka. Hak-hak ini tidak boleh dirampas dan diambil dari mereka (inalienable rights).

Ketiga, hak asasi kolektif. Ini sebenarnya penegasan kembali bahwa hak-hak asasi yang disepakati secara hokum legal formal harus ada bagi masyarakat adat Rokan Hilir. Hanya saja, berbeda dengan rezim hak asasi di bawah PBB yang cenderung individualistik, masyarakat adat menuntut agar hak-hak tersebut tidak saja dijamin bagi setiap manusia, melainkan juga bagi kelompok manusia, khususnya kelompok masyarakat adat di Rokan Hilir. Maka, dalam kaitan dengan hak atas kebebasan, masyarakat adat Rokan Hilir menekankan jaminan bagi hak atas kebebasan untuk menjadi dirinya sendiri dengan segala identitas budaya yang unik dalam kelompok budayanya. Masyarakat adat menekankan tanggung jawab komunal atas nasib hidup sesamanya dalam kelompok budayanya. Juga termasuk dalam hak atas kebebasan ini adalah, hak kolektif sebagai kelompok untuk hidup denganbebas, aman, damai dan 
tenteram tanpa intervensi dan kekerasan, khususnya intervensi dan kekerasan militer pada masa Orde Suharto ( 1967-1998).

Keempat, hak budaya. Budaya bagi masyarakat adat Rokan Hilir mencakup segala-galanya, termasuk pengetahuan dan kearifan tradisional,berhutan, berdamar, berotan, mengail, melukah, berikan, bertani, berkebun, berburu, menjerat, tarian, nyanyian, bahasa, tempattempat keramat, cerita-cerita dongeng, bekoba, inovasi dan praktik-praktik kehidupan dalam kerajinan tradisional, dan sebagainya. Ini adalah kekayaan yang sangat bernilai, bukan sekadar kekayaan fisik melainkan juga kekayaan spiritual dan moral. Oleh karena itu, masyarakat adat Rokan Hilir menuntut agar hak mereka untuk mempertahankan dan melestarikan, bahkan mengembangkan, budaya mereka harus diakui dan dijamin. Namun, karena begitu eratnya hubungan antara budaya masyarakat adat dengan alam, melestarikan budaya masyarakat adat berarti pula melestarikan alam di sekitar mereka. Seluruh budaya ini harus diperhitungkan secara serius dalam setiap kebijakan pembangunan yang berdampak pada kelestarian budaya dan ekologis masyarakat adat Rokan Hilir.

Untuk itu, perlu ada upayaupaya khusus, termasuk dari negara, untuk melindungi kekayaan budaya masyarakat adat Rokan Hilir, termasuk pengetahuan, teknologi, dan segala bentuk manifestasi budaya, serta sumber-sumber genetik, benih, obatobatan, pengetahuan mengenai ciriciri fauna dan flora, tradisi lisan atau dongeng, sastra (khususnya sastra lisan), serta seni pola penataan ruang budaya tradisional. Pemerintah perlu mengambil kebijakan legal-formalekocultur untuk melindungi kekayaan budaya agar tidak punah secara alamiah dan tidak dicuri serta dihancurkan oleh intervensi pihak luar, termasuk pihak asing.
Kelima, masyarakat adat Rokan Hilir mempunyai hak untuk menganut sistem kepercayaan serta nilai-nilai religius dan moral mereka sendiri, yang tidak boleh dilanggar oleh pihak luar. Mereka tidak boleh dipaksa untuk meninggalkan praktikpraktik religius yang mereka miliki turun-temurun. Kebebasan untuk menjalani agama mereka harus dijamin. Demikian pula, tempat-tempat suci serta obyek-obyek pemujaan mereka, termasuk binatang dan tumbuhan yang dianggapnya keramat, harus dilindungi dan dijaga keutuhannya. Menjamin hak ini akan mempunyai kontribusi sangat positif bagi pelestarian lingkungan hidup.

Keenam, hak untuk tidak diperlakukan secara diskriminatif (the right of non-discrimination). Ini sebenarnya konsekuensi dari pengakuan akan hak asasi manusia. Dengan ini mau dikatakan bahwa masyarakat adat Rokan Hilir mempunyai posisi moral dan hukum yang sama dan sederajat dengan masyarakat dan manusia lain. Oleh karena itu, segala bentuk perlakuan yang diskriminatif terhadap mereka harus dihindari. Negara memang perlu mengembangkan kebijakan paradigmaeco-culture khusus bagi mereka, tetapi kebijakan khusus ini lebih dalam kerangka perlindungan atas masyarakat adat dari invasi dan degradasi tradisi budaya mereka, dan bukan dalam pengertian perlakuan yang meminggirkan dan merendahkan martabat mereka.

Ketujuh, masyarakat ada Rokan Hilir mempunyai hak untuk ikut berpartisipasi secara penuh dalam proses politik yang menyangkut kepentingan bersama semua kelompok masyarakat. Ini terutama penting dalam kerangka pembangunan yang mempunyai dampak bagi lingkungan hidup di sekitar mereka serta bagi kelestarian tradisi budaya dan eksistensi mereka. Pendekatan politik yang menganggap mereka sekadar obyek yang bisa 
dipindahkan dan dikorbankan dalam setiap pembangunan antroposentrik sangat tidak etis dan melanggar hakhak masyarakat adat. Hak atas partisipasi ini tidak semata-mata berbentuk perwakilan mereka dalam lembaga formal seperti Lembaga Legislatif. Yang lebih penting dan menentukan adalah keikutsertaan mereka dalamsetiap proses pengambilan kebijakan, termasuk perumusan peraturan perundangundangan yang secara langsung atau tidak langsung menyangkut kepentingan mereka. Demikian pula, perlu ada mekanisme nyata untuk memungkinkan mereka mendapatkan informasi yang lengkap, akurat dan jujur tentang setiap kebijakan publik yang berdampak positif atau negatif pada kepentingan mereka.

Kedelapan, hak untuk memperoleh ganti rugi atas setiap kegiatan yang menimbulkan dampak merugikan bagi lingkungan hidup dan nilai-nilai sosial, budaya, spiritual dan moral masyarakat adat. Ganti rugi ini harus diatur dalam hukum positif agar masyarakat adat Rokan Hilir tidak dirugikan secara ekonomis, dan agar kekayaan serta nilai-nilai ekologis, budaya, sosial, spiritual, dan moral yang mereka miliki tidak punah begitu saja, khususnya oleh invasi pihak luar.

\section{Perlu Keberpihakan Pemerintah untuk mempertahankan Sosial Ekonomi Masyarakat}

Bagi masyarakat hukum adat , pengakuan pemerintah terhadap kepemilikan tanah adat, termasuk hutan adat, merupakan substansi hakiki untuk mempertahankan sistem hukum adat yang mereka jalankan. Sumber daya alam menjadi sumber inspirasi peningkatan kapasitas mereka dalam pembangunan sosial dan ekonomi dengan tetap memperhatikan kearifan ekologis yang telah berkembang di tengah-tengah kehidupan masyarakar adat Marjinalisasi hukum adat yang terjadi sepanjang sejarah rezim pemerintahan Indonesia harus ditata ulang dengan pendekatan eco-culture dalam mengembalikan hak masyarakat hukum adat dalam pengelolaan sumber daya hutan.

Pemerintah, selaku pemegang mandat pengurusan hutan sebagaimana diatur dalam UndangUndang Nomor 41 Tahun 1999 tentang Kehutanan, harus menanggalkan sikap skeptis terhadap kemampuan masyarakat hukum adat Rokan Hilir dalam pengelolaan sumber daya hutan mereka karena masyarakat hukum Rokan Hilir adat adalah kelompok masyarakat yang berpikir komprehensif dan holistik untuk generasinya saat ini dan generasinya masa mendatang dalam kerangka hukum dan kelembagaan adat yang implementatif. Fokus pemerintah adalah menjamin bahwa hak adat dengan perangkat hukum yang mengaturnya didapatkan secara adil oleh masyarakat hukum adat di Rokan Hilir.

Hak Tanah Adat berbeda dengan hak milik orang per orang yang diperoleh karena membuka tanah atau hutan. Hak milik atas tanah dapat pula diperoleh dari hak pakai atas tanah kesatuan sosial (masyarakat hukum adat) apabila hak itu menjadi tetap dan turun temurun. Hak milik mutlak tidak dikenal dalam hukum adat (Van Vollenhoven 1930). Demikian pula menurut Ter Haar (1931) dalam hak untuk beschikken (menguasai mutlak) dalam arti kata memindahtangankan tidak ditemukan dalam masyarakat suku bangsa di Indonesia. Kaidah "daerah pertuanan" (beschikkingsgebeid) tidak dapat dipindahtangankan tetap pertamatama berlaku, walaupun ada beberapapengecualian, misalnya karena peperangan dan tekanan pemerintah pusat. Ketentuan bahwa tidak ada hak milik mutlak ini dalam UUPA Tahun 1960 disebut sebagai fungsi sosial dari tanah.

Komitmen pemerintah dalam mendorong Pengelolaan Hutan 
Berbasis Masyarakat (PHBM) pada kawasan hutan negara masih lemah. Pengembangan PHBM masih kalah dengan pengembangan Hutan Tanaman Industri (HTI). Misalnya, sampai tahun 2014, perizinan Hutan Tanaman Rakyat (HTR) dan Hutan Kemasyarakatan (HKm) baru mencapai sekitar 165 ribu ha dan 44 ribu ha, masing-masingnya. Sementara luas areal HTI meningkat tajam dari sekitar 30 ribu ha pada tahun 1990 menjadi lebih dari 10 juta ha pada tahun 2011.

Sebagai salah satu skema Berbasiskan Kemasyarakatan, hutan adat perlu dipandang dalam tiga aspek penting yaitu sosial, ekonomi, dan ekologi sebagaimana perspektif pembangunan berkelanjutan yang mampu menjembatani dinamika permasalahan secara komprehensif dan holistik. Untuk mencapai hal tersebut, kebijakan yang dapat diambil pemerintah adalah sebagai berikut :

Pertama,Kebijakan sosial

politik, secara khusus melalui revisi terhadap Undang-Undang Nomor 41 Tahun 1999 tentang Kehutanan untuk mengakomodir kepentingan hakiki dari masyarakat hukum adat dan secara umum mendorong pembuatan undang-undang yang mengatur tentang masyarakat hukum adat itu sendiri dalam arti luas. Komitmen politik (political will) dari pemerintah harus diwujudkan melalui penetapan norma, standar, prosedur, dan kriteria yang mampu memaknai masyarakat hukum adat sebagai bagian sistem hukum nasional yang saling melengkapi. Kita masih memiliki modal sosial yang kuat berupa sistem kekerabatan masyarakat adat Rokan Hilir yang masih kental dan sistem kelembagaan Adat Melayu Rokan Hilir yang mengutamakan musyawarah mufakat.

\begin{tabular}{lrr}
\multicolumn{3}{c}{ Kedua, kebijakan ekonomi } \\
rakyat, & dengan & menjadikan \\
masyarakat & hukum adat sebagai \\
penggerak & utama perekonomian
\end{tabular}

wilayah dan memperluas akses mereka terhadap lembaga-lembaga keuangan yang ada dengan layanan berbasis sistem hukum yang mereka anut. Pranata ekonomi masyarakat adat Rokan Hilir dan/atau mendelegasikan tugas layanan berbasis sistem hukum adat ini pada salah satu sistem ekonomi nasional.

Ketiga, kebijakan ekologi melalui optimalisasi implementasi Hutan Tanaman Rakyat (HTR), Hutan Kemasyarakatan $(\mathrm{HKm})$, dan Hutan Desa (HD) dalam kerangka sistem hukum adat Rokan Hilir dan menjamin tata kelola adat Rokan Hilir pada lahan-lahan di luar kawasan hutan. Yang paling penting dalam kebijakan ini adalah memberikan kewenangan masyarakat hukum adat Rokan Hilir dalam menentukan tata ruang mikro berbasis ekologis untuk mencapai kemandirian pangan, kelestarian sumber daya, dan peningkatan kapasitas. Untuk mencapai tujuan tersebut, pada wilayah-wilayah Hukum adat Rokan Hilir yang pondasi sosial ekonominya didukung oleh masyarakat hukum adat Rokan Hilir, perlu dibentuk Lembaga Pelestarian Hutan Adat sebagai unit manajemen berbasis sistem hukum adat Rokan Hilir yang berbasikan eco-culture.

\section{Kesimpulan}

Terjadinya Krisis sosal ekonomi ekologis masyarakat adat disebabkan oleh cara pandang yang antroposentrik yang berbeda dengan cara pandang eco-culture yang melihat komunitas masyarakat adat adalah komunitas sosial-ekonomi ekologis, bukan hanya komunitas sosial manusia sebagaimana dipahami cara pandang antroposentrik. Dalam pandangan eco-culture masyarakat adat merupakan bagian integral dari komunitas sosial-ekonomi ekologis, komunitas alam dan komunitas metafisis-religius. Masyarakat Adat Melayu berkembang menjadi dirinya, baik secara individual maupun secara kelompok, dalam ikatan dan relasi 
Husni Thamrin; Kearifan Lokal dalam Pelestarian Lingkungan

dengan alam semesta seluruhnya, dengan seluruh makhluk di alam semesta serta berintegrasi dengan zat yang metafisis-religius dalam pelestarian sosial-ekonomi lingkungan.

Untuk membangunan sosial ekonomi lingkungan masyarakat adat Melayu harus dapat merobah cara pandang yang Antroposentrikapitalistik kepada pandangam yang Eco-culture dengan memperhatikan hak masyarakat adat, baik secara individual maupun kelompok, yang merupakan standar minimal bagi kelangsungan hidup sosial ekonomi lingkungan serta penghargaan terhadap martabat masyarakat adat. Ketujuh hak itu meliputi: a) hak atas semua hak asasi manusia yang diakui secara internasional; b) hak atas identitas sosial ekonomi lingkungan yang khas, termasuk hak untuk bebas dari kekerasan, perlakuan tidak adil terhadap masyarakat adat, ekploitasi sumber daya alam dan lingkungan , hak atas keamanan dan ketenangan hidup dalam identitas sosial ekonomi ekologis ; c) hak untuk menjalankan dan menikmati sumber-sumber ekonomi dan lingkungan dengan segala nilai sumber mata pencarian lokali,ekologis, spiritual, religius, dan moral; d) hak untuk mendapat mata pencaharian ,pendidikan , bahkan untuk mengembangkan sosial ekonomi khusus sesuai dengan tradisi dan dengan mata pencarian lokal mereka sendiri; e) hak untuk ikut berpartisipasi dalam semua proses pengambilan keputusan, khususnya berkaitan dengan pembangunan sosial ekonomi-lingkungan masyarakat adat ; f) hak atas tanah dan teritori, termasuk hak untuk mempertahankan hubungan khusus dengan tanah adat sebagai sumber penghidupan mereka sebagai warisan leluhur mereka yang berkelanjutan.

\section{Reference}

Haar, T B,. 1931 Het Adatrecht van Naderlandsch -Indie in Watenschap, Practij en Onderwijs

Keraf, A.S. 2010. Etika Lingkungan. Jakarta, Kompas

Vollenhoven, C.1930. Het Adatrecht van Naderlandsch-Indi, Dell III dalam Soerjono Soekonto, Pokok-Pokok Hukum Adat., Bandung 1984. 